\title{
P. F. H. LAUXTERMANN* \\ FIVE DECISIVE YEARS: SCHOPENHAUER'S EPISTEMOLOGY AS REFLECTED IN HIS THEORY OF COLOUR
}

\section{Introduction: Schopenhauer as an Enlightened Romantic}

IT IS ALMOST commonplace to say that the life and works of Arthur Schopenhauer confront the observer with a puzzling combination of heterogeneous ideas. "Schopenhauer's gospel of resignation is not very consistent and not very sincere", Bertrand Russell complained,' and in summing up he dismissed him as a somewhat curious, if not altogether uninteresting, outsider from the mainstream of Western thought. Thomas Mann on the other hand hailed the "mixture of Voltaire and Jakob Böhme to be found in him"'2 and maintained that precisely because of this apparent contradiction Schopenhauer was the herald of a new, as yet unborn, "pessimistic humanism". Leaving this prediction aside for the moment we may at least agree that Schopenhauer's work is a fascinating attempt to unite the currents of the 18th-century Enlightenment and of early 19th-century Romanticism. The romantic component may readily be recognized in his cult of artistic genius and in the lofty place he assigned to music in the hierarchy of arts, even though his taste in those matters was rather "classical" and to that extent still reflected Enlightenment ideals. His inclination towards mysticism and (Indian) exoticism was deeply romantic; yet the Enlightenment heritage was reflected in his firm rejection of Church dogmatism, of flirtations with the Middle Ages ("christlich-germanische Fratzen") and of obscurantism generally ("An obscurantist is a fellow who puts out the lights in order that his comrades may steal"). His romantic side is most forcefully revealed in his pessimism and in his insight into the overwhelming power of the irrational; but even here it should be noted that the irrational does not have the last word in his doctrine. True, the fact that Schopenhauer's doctrine took the form of a metaphysical system is what connects him with German Idealism - a philisophical current which may be characterized as an attempt to provide a

\footnotetext{
*Universiteit I'wente, postbus 217, 7500 AE Enschede, The Netherlands.

Received 8 October 1986.

Abbreviations: SW = Arthur Schopenhauer, Sämtliche Werke, hrsg. von Arthur Hübscher (Wiesbaden, 1948-1950). The translations of the quotations are mine.

'Bertrand Russell, History of Western Philosophy (London, 1961), p. 678.

"Thomas Mann, "Schopenhauer" (first published 1938) in Leiden und Grösse der Meister (Frankfurt a.M., 1957), p. 215.

Stud. Hist. Phil. Sci., Vol. 18, No. 3, pp. 271-291, 1987.

$0039-3681 / 87 \$ 3.00+0.00$

Printed in Great Britain.

(c) 1987 Pergamon Journals Ltd.
} 
philosophical justification for the romantic view of life. But it is equally true that no one has protested more violently than Schopenhauer against the excesses of this Professorenphilosophie der Philosophieprofessoren, which for him culminated in Hegel. It was not by chance that the only Germans he admired without restriction were Goethe and Kant. For, even though in one sense these two may be claimed to be the precursors of Romanticism and German Idealism, respectively, the spirit of the 18th-century was still very much alive in both, particularly in Kant. Schopenhauer also had a life-long predilection for the French sensualist philosophers Cabanis and Helvétius, who, although typical representatives of L'Age de la Raison, ncvertheless demonstrated at the same time the secondary nature of human reason, and thus foreshadowed in their own way the romantic reaction against the Enlightenment. Viewed in this light, a remark made by Schopenhauer's first biographer, Wilhelm Gwinner, that it was Schopenhauer's life-task "to complement the ethical realism of Kant with the physical realism of the sensualists as well as with the aesthetic realism of Goethe", becomes less paradoxical than this odd combination may appear to be at first sight. In fact, the profound truth of Gwinner's remark, in particular where Schopenhauer's epistemology is concerned, can be demonstrated through a careful examination of the decisive role his early optical studies have played in the development of his mature thought. This is what I shall set out to show in the following pages. In doing so, I shall first give a general account of Schopenhauer's interpretation of Kantianism. For a better understanding of the originality of this interpretation I shall next briefly sketch Goethe's influence on Schopenhauer, since it was Goethe's Farbenlehre which initiated Schopenhauer's own studies in the field of optics. And it was those studies which, in turn, by deepening Schopenhauer's interest in physiology, were to have a decisive influence on the development of his epistemology. I shall illustrate this on the basis of an analysis of Schopenhauer's most original contribution to epistemology: his causal theory of perception. The final section will then be devoted to a critical apprectation of Schopenhauer's epistemology in the light of subsequent developments.

\section{Schopenhauer and Kant}

Schopenhauer never ceased to claim that, unlike the Windbeutel, Unsinnschmierer and Charlatane who dominated the German universities, he was the only legitimate heir to Kantian philosophy. Rightly so? One might dismiss this question as irrelevant, since the validity of a man's thought certainly does not depend on its being true to Kant or not. Yet Schopenhauer's

\footnotetext{
${ }^{3}$ Wilhelm Gwinner, Arthur Schopenhauer aus persönlichem Umgang dargestellt. Ein Blick auf sein Leben, seinen Charakter und seine Lehre (Leipzig, 1862), p. 52.
} 
claim upon Kant's legacy stamped his entire philosophy and therefore it does make sense to present some plausible arguments both for and against the validity of this claim.

In contrast to the German Idealists, Schopenhauer sticks firmly to the Kantian distinction of "phenomenon" and "thing-in-itself". This is indeed a crucial point, in spite of the dubious ontological dualism which these terms imply. For at the heart of this distinction lies the much more fundamental epistemological dualism, which has found its classical expression in the distinction Kant made at the end of the "Transcendental Aesthetic" of the first Critique between intuitus originarius and intuitus derivativus. The former would enable its happy possessor to dispense with the necessity of discursive thinking, which is why he could only be the Urwesen, i.e. God, but never a dependant creature. ${ }^{4}$ For, as Kant asserts, the very fact that man is a thinking creature proves that he is a finite creature. Only a divine intellect could grasp everything in one act of intellektuelle Anschauung. Kant did not claim the possession of such a faculty and neither did Schopenhauer. Indeed, in Die Welt als Wille und Vorstellung he ironically confesses that he belongs to those "'profanes", who completely lack Vernunft-Anschauung and that he therefore must refrain from giving the reader any information on the Absolute, in which Thought and Being are said to be identical. ${ }^{5}$ This fundamental dichotomy between Thought and Being - which is indeed the starting-point of all critical thinking - corresponds, in the ethical sphere, to a similar dichotomy between "facts" and "ideals", or between the world as it is and as it ought to be. This "ethical realism", as Gwinner called it, is one more thing Schopenhauer had in common with Kant, which did not prevent him from presenting a rather devastating criticism of Kant's moral philosophy. ${ }^{6}$ But this does not concern us here; for us the point is that their shared "ethical realism" fortunately made both thinkers immune to any divinization of world-history. In one sense this may be called la qualité de leur défault, the défault being that, in an epoch which was marked by a growing awareness of the historical dimension of the world of nature as well as the world of man, both Kant's and Schopenhauer's outlook remained essentially unhistorical. Although in his treatise Ideen einer allgemeinen Geschichte in weltbürgerlicher Absicht, Kant proclaimed that it is man's destiny to develop his faculties in the evolution of society, he founded his Kritik der reinen Vernunft on the assumption that Euclidean geometry, Aristotelian logic and Newtonian dynamics were timeless and universally valid. He seems never to have posed himself the question why then humanity had to wait for their appearance for so long. And Schopenhauer, here a true

${ }^{4}$ Kants Werke III (Berlin: Akademie Textausgabe, 1968), p. $72 \mathrm{f}$.

${ }^{5} S W I I$, p. 30f.

${ }^{6}$ Schopenhauer's most systematic treatment of Kant's moral philosophy is in Die beiden Grundprobleme der Ethik, behandelt in zwei akademischen Preisschriften (in SW IV). 
disciple of Plato, was of the opinion that the unchangeable and everlasting is the only thing that concerns the philosopher, just as for him, as a disciple of Kant, Time was an attribute of the phenomenal world only, not of the "Thingin-itself''. The only philosophical significance the study of history can have is to find out what remains identical under all change, i.e. the fundamental qualities of the human heart and brain, which are mostly evil.

The motto of history in general should be: Eadem, sed aliter. If anyone has read Herodotus, he has, from a philosophical point of view, already sufficiently studied history. For there is already to be found everything which constitutes subsequent history: the strivings, doings, sufferings and fate of mankind, such as it results from the previously mentioned human qualities and from the physical conditions of life on earth.?

The historian may deplore this lack of historical interest, but perhaps his regret will be outweighed by a sense of gratitude that this shortcoming at least had the merit of saving those thinkers from the Hegelian-Marxist pitfall of a teleological interpretation of history.

But Schopenhauer's claim of being the only legitimate heir to Kantian philosophy has its questionable sides, too. One important reason for doubt is that Schopenhauer's Kantian distinction between "phenomenon" and "thingin-itself" did not prevent him from claiming to know what the "thing-initself" is like, and thus from constructing a metaphysical system after all. A metaphysics of sorts, no doubt, since it seeks the "thing-in-itself", not in some higher sphere, but rather in the innermost region of the empirical world-the world of inner experience. After having thus identified his own "thing-initself" with Will, he proceeds by way of analogy to identify the Will with the thing-in-itself tout court. In justice to Schopenhauer it should be added that he was well aware of the metaphorical nature of this universalized "Will". The Will is that which presents itself within us as thing-in-itself but the Will as we find and perceive it within us, is not strictly speaking the "thing-in-itself"'. What the "thing-in-itself" ultimately is, beyond its presenting itself within $u s$ as Will, we cannot know. Thus in contrast with Schopenhauer's epistemology, his metaphysics did not claim more than a kind of approximate validity, though unfortunately Schopenhauer was sometimes inclined to forget this praiseworthy restriction. ${ }^{8}$

\footnotetext{
${ }^{7}$ SW III, p. 508. cf. also Arthur Hübscher, Denker gegen den Strom. Schopenhauer gestern heute - morgen (Bonn, 1982), p. 74 and 195f.

${ }^{8}$ This is most obvious in Ueber den Willen in der Natur (in $S W I V$ ). For the metaphorical character of Schopenhauer's "Will" ef. the excellent introduction by Volker Spierling ("Erkenntnis und Natur") to Arthur Schopenhauer, Metaphysik der Natur. Philosophische Vorlesungen, Teil II (München, 1984), p. 44f.
} 
Die Welt als Wille - this is one side of the coin, the other side being Die Welt als Vorstellung. Schopenhauer identifies the phenomenal world much more unequivocally than Kant had done with the sum of our Vorstellungen, ${ }^{9}$ thus giving Kantian epistemology a distinctly idealistic twist. In so doing he acted in accordance with the "physical realism" (Gwinner) of the French materialists, especially Pierre-Jean Georges Cabanis.

This sounds wildly paradoxical and requires some explanation.

Schopenhauer's most systematic treatment of Kant is found in his "Kritik der kantischen Philosophie", which he wrote as a supplement to his main work Die Welt als Wille and Vorstellung. Speaking of the distinction between "phenomenon" and "thing-in-itself" he argues that this distinction is correct by itself, but that the way in which Kant deduced it is wrong. His criticism here runs closely parallel to one presented earlier by Schopenhauer's former teacher of philosophy in Göttingen, G. E. Schulze, in his Aenesidemus. Kant is reproached for having asserted that the phenomenon, i.e. the visual world, must have an intelligible cause which is not itself a phenomenon and therefore is not an object of possible experience. Kant does so in spite of his own repeated warnings that causality, being a category of thought, can only be applied to possible experience, since these categories have no other function than to order the phenomena of the sensual world and are meaningless beyond it. ${ }^{10}$ According to Schopenhauer, Kant's "unbelievable lack of consistency here" can only be explained by his constant fear that his "criticism" might be mistaken for a kind of Berkeleyan idealism. Now Berkeley is one of those few thinkers whose influence on Schopenhauer can hardly be overrated; and if one wishes to understand Schopenhauer's relation to Kantianism one should always keep in mind that for him Kantianism is essentially a more sophisticated version of Berkeleyanism. This is why Schopenhauer valued the first version of the Kritik der reinen Vernunft (1781) (which he claimed to have rediscovered) far above the better-known second version (1787). The first version lacks not only the patronizing remark on "the good Berkeley", but also the - admittedly not very convincing - "refutation of idealism"." Moreover in the chapter on the paralogisms of pure reason the first version contains a long digression (suppressed in the second version) in which Kant

\footnotetext{
${ }^{9}$ It is always difficult to give an adequate English translation of Vorstellung. Older Schopenhauer translations generally use "idea". Now Vorstellung corresponds indeed fairly well to "idea" in the Lockean-Humean sense, but since the Platonic Ideas are also present in Schopenhauer's work, this translation has the disadvantage of using the same word for Vorstellung and for Idee, which are wholly different things. Recent translations therefore prefer "representation". The trouble here is that this word has a more realist connotation (a representation being a representation "of something") than Vorstellung. However, since there is no better word available, we shall henceforth use it in our translation of Schopenhauer quotations.

${ }^{10} S W I I$, p. $595 f$.

"Kants Werke III, pp. $190-193$.
} 
explicitly presents his own position as a kind of idealism. ${ }^{12}$ In the essay "Zur idealistischen Grundansicht", which opens the second volume of Die Welt als Wille und Vorstellung, Schopenhauer defined this kind of idealism (which is also his own) as meaning that the phenomenal world is conditioned by the subject in a twofold way: "first materially, or as an object as such, because an objective existence is only conceivable in relation to a subject and as representation in the latter's mind; second formally, since an object's mode of existence, i.e. its mode of being represented (space, time, causality), has its origin in, and is preconceived by the subject. Thus, simple or Berkeleyan idealism, which regards the object as such, is immediately joined by Kantian idealism, which regards the specific mode of being an object." "No object without a subject"; that is for Schopenhauer the important discovery made by Berkeley, to which Kant added "only" the formal conditions under which any object must necessarily present itself: space, time and causality. Since these conditions are a priori known to us, they are a function of our intellect and therefore they are just as subjective as our sensations are. To be sure, Schopenhauer adds at once that the thesis "no object without a subject" has as its necessary corollary the equally irrefutable thesis. "no subject without an object". "For quite as false as the thesis of the uneducated mind: the world, the object, would still be there even if there were no subject, is this one: the subject would still be a knowing subject even if it had no object, i.e. no representation at all. A consciousness without an object is no consciousness". ${ }^{14}$ This, however, is still quite compatible with Berkeleyanism, and is indeed not directed against Berkeley, but rather against Fichte. For while it is true that Berkeley (unlike his successor Hume) only denied the existence of material substances and was firmly convinced of the existence of mental substances ("spirits"), this did not imply for him that "I am the author of my ideas"'. Berkeley in fact denied explicitly that this would be the case. ${ }^{\text {is }}$ In keeping with traditional British empiricism, Berkeley regarded perception as an essentially passive process, in which the mind obtains its information from the outside. The difference is that for him the outside agent is not - as it was for his predecessor Locke - "material substance". Rather, it is God, whose ideas are the objects of our perception. Of course the atheist Schopenhauer did not share this particular point of view, nor did he adopt the passive interpretation of perception. But the point is that the thesis "no subject without an object" does not necessarily imply the "material" nature of the latter. As such it is therefore still entirely compatible with Berkeley's

\footnotetext{
${ }^{12}$ Ibid., IV, pp. $230-238$.

${ }^{13} S W I I I$, p. 9.

${ }^{14}$ Ibid., p. 17.

${ }^{15} \mathrm{Cf}$. George Berkeley, Three Dialogues between Hylas and Philonous (in 'Bibliotheca Philosophorum', Vol. V, Lipsiae, 1913), p. 68.
} 
brand of idealism. But Schopenhauer goes further. There are, he says, two fundamentally distinct, though equally legitimate, conceptions of the intellect. There is the subjective conception, which takes consciousness as its point of departure: this is the only view proper to philosophy. The reason is that every science must depart from that about which it has immediate certainty; and for philosophy that is consciousness. Yet for the same reason empirical science takes the objective world as simply given. Well then: in so doing science shows that it is not the intellect that has generated nature, but nature that has generated the intellect, since it took a long time before the first eye - upon which, according to idcalism, the existence of the world depends - could open itself. ${ }^{16}$ Moreover, as the word "eye" already suggests, perception is a physiological process, and so is thinking. "A thinking creature without a brain is like a digesting creature without a stomach", says Schopenhauer. ${ }^{17}$ Such a statement sounds hardly less drastically "materialistic" than the notorious assertion of Schopenhauer's favourite Cabanis about the brain, which secrets thoughts just as the liver secrets gall. Thus Berkeley and Kant are right and Cabanis is also right: a classical case of an antinomy, as Kant would have called it! Yet I would suggest that there are at least two reasons not to take this antinomy too seriously. First: Berkeleyanism is an idealism of sorts, just as we have seen Schopenhauer's metaphysics (which was in part intended to solve this antinomy) to be a metaphysics of sorts. Berkeleyan idealism is not only quite different from Fichtean, but also from Platonic idealism, which has become the classical form of idealism in the West. All these idealisms share only one thing beyond their common predilection for the literary genre of the dialogue, which enables the author to take care that his own mouthpiece "Socrates" and "Philonous", respectively - in the end always gets the upper hand. This common feature is a lack of trust in the world-view of "common sense". But this distrust can take two diametrically opposed forms: distrust of the senses (Plato) and distrust of the constructions of the intellect (Berkeley). In scholastic terms: Plato is an extreme realist, Berkeley an extreme nominalist. Or, metaphorically: Berkeley is like a prisoner in Plato's cave, who impatiently shrugs off the reports of the escaped prisoner and stubbornly clings to the shadows on the wall as the sole reality. Let us listen to what Berkeley has to say on this point (he aims it at Malebranche, but it might equally well have been aimed at Plato):

Few men think, yet all have opinions... . Hence men's opinions are superficial and confused. It is nothing strange that tenets, which in themselves are even so different should nevertheless be confounded with each other by those who do not consider

${ }^{16} S W I I$, p. 35f.

${ }^{17} S W I I I$, p. 70. 
them attentively. I shall not therefore be surprised if some men imagine that I run into the enthusiasm of Malebranche; though in truth I am very remote from it. $\mathrm{He}$ builds on the most abstract general ideas, which I entirely disclaim... He asserts that we are deceived by our senses, and know not the real natures or the true forms and figures of extended beings; of all which I hold the direct contrary. So that upon the whole there are no principles more fundamentally opposite than his and mine ${ }^{18}$ (my italics, P.L.).

In brief, Berkeley's message is "trust your five senses, and the rest is talk". Not quite so of course: there is still God. But obviously Berkeley was not an "idealist" in the Platonic sense of the word at all. He was a nominalist, and his polemic against the concept of "material substance"' was probably aimed less at the attribute "material" than at the concept of "substance" itself, though it fell to his successor Hume to draw the full consequences from this insight by denying "mental" substance as well. Thus it is quite odd to see that, in the third book of Die Welt als Wille und Vorstellung, Schopenhauer, who was no less of a nominalist than Berkeley and Hume, gives the Platonic Ideas such an important place in his system. Schopenhauer may well have been somewhat uneasy about this himself, as he used to insist that the Platonic Ideas are something quite different from general concepts. The reason is that, though not in space and time, they are nevertheless sinnlich erfassbar (especially for the artist's eye), because they are the timeless archetypes of the phenomenal world. The Ideen are, in scholastic terms, universalia ante rem, the Begriffe universalia post rem. But to us this smacks rather of Goethe's Urphänomene than of Plato's Ideas, which are not at all "sinnlich erfassbar", but, on the contrary, are accessible only to pure thought, preferably to mathematical thought (which Schopenhauer disliked almost as much as Goethe did). The Platonic Ideas clearly form a Fremdkörper in Schopenhauer's system, for in their original version they demonstrate Plato's belief in the fundamental reasonableness and divinity of the world, whereas Schopenhauer's Willdominated world is very unreasonable and devilish rather than divine in nature. I can find one reason only for this "antinomy", which to my mind is far more fundamental than the one cited above. The reason is that, as a (somewhat prodigal) child of the Enlightenment, Schopenhauer shrank intuitively away from the consequences of irrationalism. This is confirmed by the paradox that in Schopenhauer's view the intellect, though originally an instrument and servant of the Will, can nevertheless, in its most enlightened form, see through the Will and even ultimately vanquish it.

Be all this as it may, there is one more reason for not taking Schopenhauer's original antinomy too seriously. What physiological processes in the brain and

\footnotetext{
${ }^{18}$ Berkeley, op. cit., p. $67 \mathrm{f}$.
} 
in the sense-organs have in common with psychological processes in the mind is at least that, in Schopenhauer's words, they are confined to the region "underneath the skin", i.e. that they have both to do with the individual knowing subject. And here, I think, lies the fundamental difference between Kant and Schopenhauer. Kant's basic aim was to overcome Humean scepticism, however gratefully he acknowledged that it had awakened him from his "dogmatic slumber". Kant derived his confidence that this would be possible from the evident success of modern science in explaining natural phenomena. It is surely not by chance that the motto for the second version of the Critique of Pure Reason is borrowed from Francis Bacon, the prophet of a new Humanity and its calling actively to act upon Nature and thereby to transform it, rather than merely passively to contemplate it. Humanity indeed, for we have here to do with a process that is essentially collective, or rather intersubjective - in view of the tremendous importance of the creative individual, in science no less than in art. Kant tried to find out what principles guide human reason by an internal investigation of its most successful products: pure mathematics and mathematical physics. By means of this transzendentallogische approach (which he insisted on keeping sharply distinguished from any "psychological" or "anthropological" approach) he hoped to demonstrate the a priori validity of certain forms of thought for all mankind - nay, for every possible thinking creature - while at the same time showing their inherent limitations by demarcating carefully the realm in which they could alone be meaningfully used. The contrast with Schopenhauer is obvious. Although the latter had a considerable reading in contemporary science and eagerly used everything that might fit into his metaphysical system, ${ }^{19}$ he was in fact but little interested in science for its own sake. His basic aim was to explore the deeper layers of human personality by way of introspection, thus showing the way to salvation; consequently his epistemology is far more concerned with the - basically psychological problem of the origins of immediate, perceptual knowledge than with the problem of the origins and legitimation of scientific knowledge. Or, to phrase the matter in Popperian terms, Kant's main interest was in the problems of "World 3", Schopenhauer's in those of "World 2"' " Schopenhauer may be regarded as a precursor of those thinkers who, like Helmholtz and Lange, attempted to reinterpret Kantian philosophy in a psychological and even physiological sense. They did so under the slogan "Back to Kant!", thereby reacting against the metaphysical systems of German Idealism. Justified as this reaction was, its neglecting of the transcendental and logical aspects of Kant's

\footnotetext{
${ }^{19}$ Once more this is most conspicuous in Ueber den Willen in der Natur (see note 8).

${ }^{20}$ Cf. Karl R. Popper, Objective Knowledge. An Evolutionary Approach, especially Chapter 3: 'Epistemology without a knowing subject' (Oxford, 1972), pp. 106-153.
} 
work led almost inevitably to the positivism of Mach, which, like the earlier "psychologism" of Fries and Beneke, tended to obliterate the fundamental difference between Berkeley and Hume at one hand and Kant at the other. This in turn provoked the reaction of Frege, Marburg Neo-Kantianism, Husserl and others, who rightly protested against the intrusion of "psychologism" in the realm of logic, mathematics and science. It should not be forgotten, however, that positivists like Mach were, in their psychology, conventional associationists, quite unlike Schopenhauer or Helmholtz. And that is why, in spite of his "World 2"'-outlook, a man like Schopenhauer was not unjustified in regarding himself as a legitimate heir to the Kantian revolution. For the active role of the human mind in constituting knowledge, which Kant so emphatically stressed, is indeed not confined to the scientific level, but is already present at the immediate, perceptual level. Kant himself, however, owing to his "World 3"'-outlook, has precious little to say on the subject. "Knowledge", he asserts at the beginning of the "Transcendental Logic", "has two sources, namely receptivity for impressions and spontaneity in forming concepts: the former being the faculty of receiving representations, the latter that of recognizing an object by these representations. By virtue of the former an object is given to us, by virtue of the latter it is thought". ${ }^{21}$ Whereupon Schopenhauer retorts: "That is false: for in that case the impression, for which alone we have mere receptivity - which therefore comes from without and is alone, strictly speaking, "given" - would already be a representation, nay, already an object. But it is nothing but a mere sensation in the sense-organ, and it is only by using Understanding (i.e. by applying the law of causality) and the forms of perception (space and time) that our intellect transforms this mere sensation into a representation which from now on stands before us as an object in space and time. ..,"22

Here we have Schopenhauer's epistemology in a nutshell. In its most elaborate form it is to be found in the second version of Schopenhauer's doctoral dissertation Ueber die vierfache Wurzel des Satzes vom zureichenden Grunde (1847), particularly in the long section 21 ("Apriorität des Kausalbegriffes - Intellektualität der empirischen Anschauung - Der Verstand'), which, in this form, is entirely new in the second version. Further on we shall compare both versions in some detail; suffice it here to say that, shortly after the publication of the first version (1813), two decisive events occurred in Schopenhauer's intellectual biography. One was his discovery of Indian thought - especially the Upanishads - which was to lay the foundation for Schopenhauer's metaphysics, whereas in the first version of the Vierfache Wurzel metaphysics of whatever kind had still strictly been rejected.

\footnotetext{
${ }^{21}$ Kants Werke $I I I$, p. 74 and $I V$, p. 47 (my translation).

${ }^{22} S W I I$, p. 520.
} 
The other event was Schopenhauer's encounter with Goethe's theory of colour. And it is his resulting optical studies which were to lead Schopenhauer to the formulation of his own theory of causality; a theory which is still latent in the first verion of the Vierfache Wurzel, and which he stated explicitly in Ueber das Sehn und die Farben for the first time (1816). This little book is the literary fruit of Schopenhauer's short-lived collaboration with Goethe in the field of optics. Before discussing it, we shall briefly sketch Schopenhauer's relation to Goethe.

\section{Schopenhauer and Goethe}

The quintessence of much of Schopenhauer's later criticism of Kant is already anticipated in a significant complaint, made while he was a student, of Kant's "complete lack of contemplation". This contrasted unfavourably with the other great representative of the German mind: Goethe. ${ }^{23}$ Schopenhauer's criticism springs from the same source as his impatient comment on Kant's definition of the two sources of knowledge, which, as we have seen, confined the active role of the human mind to the conceptual level: According to Schopenhauer, Kant neglects intuitive (i.e. perceptual) knowledge ("anschauliche Erkenntniss") in favour of abstract thinking, "though the latter derives all its importance and value only from the visible world, which is infinitely more important, more general and richer in content than the abstract part of our knowledge"'. ${ }^{24}$ According to Schopenhauer this one-sidedness was responsible for Kant's abstruse, scholastic jargon, which made him speak of, for example, "transcendentale synthetische Einheit der Apperception", where the simple word "Vereinigung" would have done, and which provided his selfproclaimed "successors", Fichte, Schelling, and above all Hegel with a welcome excuse for concealing their lack of thought behind incomprehensible words. ${ }^{25}$ Schopenhauer by contrast, who had an excellent prose style and who always remained grateful to his father for having given him the opportunity to look around in the world before entering the university, always stressed the necessity of submitting all abstract concepts to the test of perceptual evidence. As an antidote against the verbiage of a certain kind of philosophical speculation this is an admirable precept. But it shows its limitations when confronted with the methodological needs of modern science. Schopenhauer himself unwillingly demonstrated this when, after having made the personal acquaintance of Goethe (1814), he allowed himself all too easily to be won over to the latter's ill-fated polemic against Newton's theory of colour. Their common ground was indeed what Gwinner called Goethe's "aesthetic

\footnotetext{
${ }^{23} \mathrm{Cf}$. Hübscher, op. cit., pp. 66 and 130.

${ }^{24} \mathrm{SW} I I$, p. 511.

${ }^{25}$ Ibid., p. 508.
} 
realism'. Realism: for this healthy pagan and man of the world was always distrustful both of philosophical speculation (especially if it took a christianizing form, as in the later Schelling, or a panlogistic form, as in Hegel), and of the "morbid" inclination of Romanticism towards introspection and escapism. Aesthetic realism: for the poet and Naturkind disliked the "mechanistic" approach to Nature of modern science. Though he always spoke of pure mathematics with respect, Goethe was opposed to its application to Nature because of the quantitative reductionism it implied. And, although he sometimes did make use of simple experiments, he was on the wholc opposed to the experimental method as well, because it "puts Nature on the rack".

Man himself, so far as he avails himself of his sound senses, is the greatest and most exact physical apparatus possible; and it is precisely the greatest evil of modern physics that is has, so to say, separated experiment from Man, wanting to know Nature only from the data of artificial instruments, and even to demonstrate Nature's achievements that way, thus reducing those achievements to what can be demonstrated that way. ${ }^{26}$

It goes without saying that this attitude connects Goethe with the romantic Naturphilosophie which was so popular in Germany at the time, in spite of his professed anti-romanticism and of the critical distance he kept towards a man like Schelling. The main difference is that Goethe, who, in his own words, "lacked the proper organ for philosophy", 27 was less speculative and more empirical; but "empirical" in the naive sense of unconditionally trusting the testimony of the senses. This is not to say that Goethe stopped at isolated phenomena. For example his botanic studies resulted in a theory on the metamorphosis of plants, a concept which clearly transcends immediate observation. What Goethe is always seeking for is the Urphänomen. Normal phenomena are only variations of the Urphänomen, which differs from the concepts of "mechanicist" science in that it can be aesthetically imagined. In the case of colour-phenomena this Urphänomen is the elementary polarity of light and darkness, or of white and black. This explains Goethe's bitter opposition to Newton's Opticks with its theory that white light is compounded of rays of different refrangibility. For Goethe white light must of necessity be simple, since it appears as such to the eye, which does not deceive us.

That all colours, mixed up together, produce white, is an absurdity which together with other absurdities people have been accustomed to repeat credulously and against all visual evidence, already for a century. ${ }^{28}$

\footnotetext{
${ }^{2 h}$ Goethes Werke in vierzehn Bänden (Hamburg, 1948-1960) VIII, p. 473 (my translation).

${ }^{27}$ Ibid. XIII, p. 25.

${ }^{28}$ Ibid., p. 450.
} 
For Goethe, colours owe their existence to the interplay of light and darkness by means of a turbid (trübes) medium; they are therefore of a shadowy nature (skieron).

Schopenhauer shared the admired poet's dislike of the mathematical experimental method of the official science of his day, albeit to a lesser degree (one wonders what he would have said of contemporary science which, though no longer "mechanicist" in the classical sense, is more mathematical than ever and thus hardly meets Schopenhauer's requirement of perceptual evidence!). Thus he was readily convinced of the fundamental soundness of Goethe's position in this controversy. However, his Kantian upbringing ("Kantian" in the "psychologist" interpretation we described in the preceding section) made him seek the ultimate explanation of the phenomenon of colour in the subject, which in this case means the perceiving eye. He agreed with Goethe on the homogeneity of white light and on the shadowy nature of colour, but he believed to have found the cause of the skieron, not in the activity of light itself, but in the activity of the retina, which may be either fully active or fully passive or partially active. In the latter case the phenomenon of colour arises, and the different colours correspond to different fractions of the full activity of the retina. ${ }^{29}$

It cannot, in the present context, be our aim to discuss the merits and shortcomings of Schopenhauer's theory of colour in full. What is of interest to us here is the influence which Schopenhauer's optical studies have exerted on the development of his epistemology. The main point is that it deepened his interest in, and his knowledge of, physiology, especially of the sense-organs and of the brain. This in its turn helped him clarify his position with respect to Kantianism. If already the sensation of colour (or, by extension, any other sensation) is not something purely passive, but is rather the activity (provoked, no doubt, by an outward stimulus, in this case by light) of a small piece of nervous tissue at the back of the eyeball, how much more must this be true for the functions of such an infinitely more complicated organ like the human brain! For it takes a decisive step to recognize colour, which originally is nothing but a sensation in the eye, as a quality of an external object, which acts upon the eye. In the sensation of "red" there is nothing which entitles us to say "this object is red". Such an object exists only for Understanding (Verstand), which is a function of the brain. Now Schopenhauer was of course not the first to point out the crucial role of the brain in the process of transforming the raw material of sensation into conscious perception. His reading of contemporary physiologists gave him an important hint. Already before the time of his contact with Goethe he had read Flourens, who discovered the functions of the big and the small brain. Now he made the acquaintance of the aforementioned

${ }^{29}$ SW I ('Ueber das Sehn und die Farben”), pp. 25-35. 
Cabanis ("Rapports du physique et du moral de l'homme"); and later followed Magendie, Charles Bell, Marshall Hall and above all Bichat ("Recherches physiologiques sur la vie et la mort"). His originality lies in his attempt at combining their purely physiological findings with Kant's purely transzendentallogische doctrine of the a priority of the law of causality. In this combination lies the strength as well as the weakness of Schopenhauer's epistemology, which we shall now inspect more closely.

\section{Schopenhauer's Causal 'Theory of Perception}

"Alle Anschauung ist eine intellektuale" - this is the lapidary statement with which the first chapter ("On vision") of Ueber das Sehn und die Farben ${ }^{30}$ opens. Naturally this is not to be understood in the Schellingian-Hegelian sense of a higher form of knowledge. Quite the contrary, for we deal here with knowledge in the primitive, still unreflected form that man shares with the higher animals. Schopenhauer calls this faculty Vrestand, thus considerably modifying Kantian terminology. For Kant Vrestand was a discursive faculty; its instrument was the complicated mechanism of the twelve categories. In his "Kritik der Kantischen Philosophie" Schopenhauer throws 11 of these out the window; and he switches the only remaining one, causality, from the discursive to the intuitive domain, i.e. the domain of perception. He does this also in his treatise on vision and colour. Perception (Anschauung) should be clearly distinguished, according to Schopenhauer, from mere sensation (Empfindung). Perception involves the recognition of objects, which is possible only because our understanding (Verstand) relates any impression the body receives to its cause, which it then localizes in space. This immediate inference from an effect to its cause is the only function of Understanding - a faculty which, as already mentioned, we share with the higher, and to some extent even with the lower, animals. Reason (Vernunft) on the other hand belongs to mankind only. This is the faculty of forming concepts by way of generalizing from sense experience (for Kant, it will be remembered, Reason was the faculty of conceiving "ideas" that have no counterpart in sense experience - God, World, Immortality of the Soul; but Schopenhauer will have nothing to do with that). It is concepts like these which make possible the formulation of judgments (Urteile) and thus of science. Now of course the law of causality in 
its articulated form is also a judgment, and insofar it belongs to the domain of Reason. However, its unconscious, immediate application is the work of Understanding; as such it precedes discursive knowledge. And it precedes experience likewise, since it is the very thing which makes experience possible. The sense alone will not do. They are no more than spots on the body which are to a heightened degree susceptible to the effects of other bodies. Each of the senses is susceptible to one specific kind of effect, to which the others are little or not at all susceptible. So far Schopenhauer is in accordance with Johannes Müller's famous law of specific sense-energies. He departs from it, however, in maintaining next that the difference in sensation between the five senses has nothing to do with the nervous system itself, but only with the manner in which it is affected." Now it is true that at the time of Schopenhauer's writing Müller's law was not yet known to science; yet when almost 40 years later Schopenhauer published the second edition of Ueber das Sehn und die Farben it had bcen known for a long time. The more astonishing, then, that, in this thoroughly revised edition, Schopenhauer not only left intact his old opinion (which he had derived from Cabanis' Rapports du physique et du moral de l'homme) but did not even bother to dispute Müller's theory. He simply seems not to have taken notice of it. Maybe Wilhelm Ostwald was right in ascribing this omission to the circumstance that Schopenhauer used to take more notice of the discoveries of foreign than of German investigators, whom he was a priori inclined consider as corrupted by university philosophy. ${ }^{32}$

However this may be, what interests us here is that Schopenhauer's theory of perception enabled him, in spite of his rejection of Kant's proof of the a priority of causality, ${ }^{33}$ to cling nevertheless to this a priority, for which he believes to have found a better proof than Kant's. "The child", Schopenhauer says in an interesting passage which reads as an anticipation of modern developmental psychology and which we shall therefore quote at some length,

\footnotetext{
${ }^{31}$ Ibid., p. $8 \mathrm{f}$.

${ }^{32}$ Wilhelm Ostwald, Goethe, Schopenhauer und die Farbenlehre (Leipzig, 1918), p. 108.

${ }^{33} \mathrm{Cf}$. Section 23 of the second version of the Vierfache Wurzel (SW $\mathrm{S}$, pp. 85-93) and Section 24 of the first version ( $S W V I I$, pp. $31-44)$. Just as he agreed in principle with Kant's theory of the Thing-in-itself, but rejected the way in which Kant had deduced it (see above, p. 275), so he agreed in principle with Kant's theory of the a priority of the law of causality, but rejected the way in which Kant had deduced it. According to Kant the objective nature of the temporal succession of our perceptions is warranted only by the law of causality; Schopenhauer, however, argues that empirical phenomena can very well succeed each other without being causally related. According to Schopenhauer, Kant makes here the same mistake as Hume, but in the opposite direction: whereas Hume regarded all following from as a simple following upon, Kant regards each following upon as a following from, which is just as wrong. It should be added, however, that more recent accounts of Kant's doctrine of causality have thrown some doubt on this Schopenhauerian interpretation of the doctrine.
} 
during the first weeks of its life, feels with all its senses; but it does not perceive, does not apprehend; therefore it gazes stupidly into the world. However, it soon begins to learn to use Understanding, to apply the law of causality - of which it is aware before any experience - and to connect this law with the likewise a priori forms of all knowledge: space and time. Thus it proceeds from sensation to perception, to apprehension; and from now on it looks with sensible, intelligent eyes into the world. Since, however, each object affects each of the five senses in a different way, the effects nonetheless pointing to one and the same cause - which, just because of this, presents itself as an object - the child learns to perceive by comparing the diverse impressions it receives from the same object: it handles what it sees, looks at what it handles, traces back the sound to its cause, invokes the help of smell and taste, and finally it takes into account the effects of distance and lighting upon the eye. It gets acquainted with the effects of light and shadow and finally, with many pains, also with perspective, the knowledge of the latter resulting from the union of the laws of space and the law of causality, which are both present a priori in consciousness and only wait for application. Thereby the modifications which undergo both the inner conformation of each eye and the position of both eyes towards each other must be taken into account as well. At the level of Understanding, all these combinations are made already by the child; at the level of Reason, i.e. in abstracto, only by the the optician. Thus the child makes the manifolds sense data, according to the laws of understanding, of which it has $a$ priori knowledge, into perception, by virtue of which the world presents itself as an object for the child. It is only much later that it learns to use Reason; only then it begins to understand speech, to speak himself and, strictly speaking, to think. ${ }^{34}$

Schopenhauer illustrates all this by refcrring to some well-known optical phenomena. Thus he points to our perceiving objects upright, even though, due to the crossing of the lightrays when passing through the pupil, their impression on the retina is upside-down. There is also the fact that we perceive each object as single, although our two eyes are affected by it independently, so that we get a double impression. In all such cases Understanding immediately, and therefore unconsciously, corrects the false impression, tracing back the effect to its cause by following the direction from which the sensation came. It would not be able to do this if it had no a priori knowledge of the law of causality. ${ }^{35}$

Now it is all very well thus to stress the intellectual nature of perception in order to save the a priority of causality. But it cannot be denied that the quoted passage about the young child also shows that the application of such an $a$ priori given insight is something that must be learned. This truism seems to me illustrative of the difficulties into which Schopenhauer's way of thinking

\footnotetext{
${ }^{34} \mathrm{SW} I$ ('Ueber das Sehn und die Farben'), p. 10.

${ }^{35}$ Ibid., p. $10 \mathrm{ff}$.
} 
almost inevitably leads, and which we shall examine in the next and final section.

\section{Conclusions}

On 23 February 1855, at Königsberg, young Hermann Helmholtz delivered a lecture in which he sketched a theory of perception, whose basic concept, "unconscious inference", is quite reminiscent of Schopenhauer's theory of the intellectual nature of perception. ${ }^{36} \mathrm{~A}$ case of plagiarism? Inevitably it was regarded as such by the always slightly paranoid Schopenhauer. But of course it is quite possible that two thinkers arrive independently at similar conclusions. In this particular case this is even probable, in view of the general lack of interest of German scientists of that time in speculative philosophy - a natural reaction to the preceding epoch of German Idealism and romantic Naturphilosophie which, after the bitter remark of Alexander von Humboldt, was responsible for Germany's relative backwardness in scientific development. ${ }^{37}$ In another lecture, delivered more than two decades later, Helmholtz implicitly defended himself against the charge of plagiarism by publicly dissociating his theory from Schopenhauer's. He calls Schopenhauer's theory "unclear and unjustified" and informs his audience that in later publications he has deliberately avoided the name "unconscious inference", in order to escape being confused with "Schopenhauer and his adepts". ${ }^{38}$ In his famous Handbuch der physiologischen Optik Helmholtz indeed uses the term "inductive inference" instead of "unconscious inferencc", and stresses the importance of memory in the perceptual process, referring there to Stuart Mill's System of Logic. ${ }^{39}$ This is more than a mere question of terminology. Although Helmholtz viewed himself as standing in the Kantian tradition, as we have already seen, he was always anxious to present his views as strictly "empiricist". Despite the striking similarity between his own theory of perception and Schopenhauer's he may therefore indeed have been sincerely puzzled by the way in which the latter presented it. For the Schopenhauerian version of the doctrine of unconscious inference does suffer from an inherent contradiction, which was due to Schopenhauer's attempt to adapt Kantian a priorism not only to the findings of physiology (Helmholtz did that, too), but also to the needs of his metaphysical system.

\footnotetext{
"Hermann Helınholtz, 'Ueber das Sehen des Menschen', in Philosophische Vorträge und Aufsätze (Berlin, 1971), p. 76.

${ }^{37}$ Briefe von Alexander von Humboldt an Varnhagen von Ense aus den Jahren 1827 bis 1858 (Leipzig, 1860), p. 90. The way in which Naturphilosophie practised, say, chemistry, is nicely characterized there by Humboldt as "a chemistry, in which you need not wet your hands".

${ }^{38}$ Helmholtz, Die Thatsachen in der Wahrnehmung (Berlin, 1879), p. $27 \mathrm{f}$.

${ }^{39}$ Helmholtz, Handbuch der physiologischen Optik (2. Aufl., Hamburg, 1896), pp. $578-583$.
} 
The contradiction is really quite obvious. According to Schopenhauer, like the Anschauungsformen of space and time, the law of causality is known to us a priori and is therefore (my italics, P.L.) wholly subjective. Yet on account of the very same law of causality we know, again according to Schopenhauer, that our sensations have external causes, which exist independently of us. This seems to imply either that Schopenhauer's subjective idealism is self-refuting or that our understanding deceives us. Or is there perhaps a way out?

Schopenhauer would no doubt have answered (provided that he had not meanwhile lost his temper with this slow-witted opponent) that the contradiction is only apparent. In a sense, he would say, our understanding does deceive us, insofar as its domain is strictly confined to Die Welt als Vorstellung, which is nothing but the "Veil of Maya", i.e. at the last resort an illusion. But inside its own domain its laws are valid a priori, and insofar the information with which it provides us is perfectly reliable. But this seems hardly a satisfactory answer, since it raises at once the question of the soundness of a metaphysical dualism, which inevitably leads to such (albeit, for all we care, only apparent) contradictions.

Next to the introduction of the causal theory of perception, and apart from a load of fresh invectives against Schopenhauer's philosophical rivals the introduction of this metaphysical dualism is the second important difference between the first and the second versions of Schopenhauer's main epistemological writing Ueber die vierfache Wurzel des Satzes vom zureichenden Grunde. Surely this new element does not improve the unity of the book. The first version had no other aim than to shed some new light upon one specific problem of (traditional) logic: the different forms under which the principle of sufficient reason can appear according to its subject-matter. But in the second version this logical investigation has been subordinated to the needs of the metaphysical system that Schopenhauer had conceived in the meantime. Let me mention just one significant detail. In the first version we read that, if we strip subject and object of all attributcs that belong to a specific concrete case, there remain two abstractions: "pure intellect" at one hand, and "pure matter" at the other. And Schopenhauer continues; "This much becomes clear, however, that our investigation does not end in the rigidity of a thing-initself (my italics, P.L.), since also these two... can be conceived of and are meaningful only in mutual relationship, but disappear without it". ${ }^{40}$ This passage not only treats the thing-in-itself as the limit of human understanding and therefore as unknowable, just as Kant had done; it more-over completely 
rejects the entire concept. ${ }^{41}$ Of course this passage was suppressed in the second version, which does "end in the rigidity of a thing-in-itself". True, this thing-in-itself is neither Pure Intellect (i.e. the hypostasized subject) nor Pure Matter (i.e. the hypostasized object), but something prior to both - the Will. Subject and object are and remain nothing but the two poles of Die Welt als Vorstellung and so far Schopenhauer has remained true to his original conception. But what is new is that Schopenhauer had meanwhile learned from Indian thought that the whole Welt als Vorstellung is nothing but the Veil of Maya, behind which - and this is his own contribution - the allpervading Will lurks as the ultimate reality. As mentioned before, Schopenhauer's acquaintance with this exotic world dates from roughly the same period as his optical studies which resulted in his theory of colour and in his causal theory of perception - that is to say, the period between the publication of the first version of the dissertation (1813) and the publication of his life work Die Welt als Wille und Vorstellung (1818). This is why these five years are of such decisive importance in Schopenhauer's development - in fact it is the only period for which one can speak of any development at all. For after having completed his philosophical system at the age of 30 , he spent the remainder of his rather long life with being right and with pouring scorn upon a world which was not prepared to give him his due. ${ }^{42}$ It is as tempting as it would be pointless to speculate on how Schopenhauer's thought might have developed in case of a less premature conclusion. Might he not have found the way out at which we hinted above, that is the way from critical idealism to critical realism?

\footnotetext{
${ }^{41}$ Of course young Schopenhauer rejected it for other reasons than did the German Idealists. Whereas they rejected it because they believed in the metaphysical identity of Thought and Being, Schopenhauer rejected it because at this stage of his development he still remained strictly within the limits of the empirical world and therefore regarded the Thing-in-itself as a metaphysical residue in Kant's thinking. In section 42 of the first version of the Vierfache Wurzel Schopenhauer has very neatly illustrated the difference between his own view on the subject - object relation and that of German Idealism. We there read: "Should the identity of the subjective and the objective, claimed by Naturphilosophie, mean nothing but this indifference [namely that it amounts to the same thing whether one says: "the objects have these or those particular attributes", or: "the subject perceives in this or that way", P.L.], I completely agree with it. I doubt, however, whether it means only this, since, in order to understand this, no intellektuale Anschauung is needed, but only reflection. If one wishes to call two things, the one of whom cannot be conceived without the other, for that reason one thing, I shall therefore not dispute this, for re intellecta in verbis simus faciles, although I see only a necessary relation, which is admittedly the only predicate of these two related things. Exactly the same relationship exists, however, between other things, like cause and effect, father and son, or brother and sister. Neither of these can as such be thought of otherwise than together, since one term of each couple derives its meaning only from the other. Yet they are never for that reason called one, but always two, though admittedly they have in concreto always other predicates as well" ( $S W V I I$, p. 70$)$. Perhaps the difference might be summarized by saying that for Naturphilosophie subject and object were identical, but for Schopenhauer only correlative.

${ }^{42}$ This is not to deny that the later Schopenhauer, too, has written many delightful treatises (e.g. the already mentioned treatises on ethics, or the second volume of Die Welt als Wille und Vorstellung), but these are at the last resort only elaborations of the main work.
} 
Hopefully it has in the meantime become clear that indeed there were from the beginning tendencies in Schopenhauer which pointed in that direction. Obviously his optical studies might have reinforced them. But even his "great discovery" of the all-pervading Will might have reinforced them as well, if it had not been turned into a new metaphysics, i.e. if Schopenhauer's unjustified hierarchical distinction between inner and outer experience had not persuaded him to treat the phenomena of inner experience, not as phenomena, but as revelations of the thing-in-itself. In our imaginary case his profound psychological insight into the secondary nature of the intellect might have fertilized his epistemology, in that it might have guided him towards a new interpretation of the a priority of causality, in the sense of a biological urge to seek regularities in our environment. But in the way his epistemology is actually presented it suffers from two defects which, moreover, are mutually incompatible. The first of these is due to Schopenhauer's transforming Kant's phenomenal world into the Welt als Vorstellung, the second to his choosing nevertheless to stick to Kant's apodictical conception of the a priori. As to the first, Schopenhauer's transforming of Kant's phenomenal world into the Welt als Vorstellung tempted him to consider the a priori as being by definition subjective, which is simply wrong. Take, for instance, the propositions of logic. These are certainly a priori valid, but for that very reason they are not subjective. Take, on the other hand, the principle of causality. For the reasons already given by Hume, this is in one sense subjective, but for that very reason it is not a priori valid. It may be nonetheless a priori (or so we believe with Kant and Schopenhauer), but only if we accept Popper's distinction between psychologically or genetically a priori and a priori valid. ${ }^{43}$ Such a distinction, however, would have been impossible for Schopenhauer to accept, since, in spite of his subjectivism, he stuck firmly to Kant's apodictical conception of the $a$ priori and thus ran into the contradiction, pointed out in the above. On the other hand the Popperian distinction has the merit of stressing the importance of learning (which is always to a large extent learning by mistakes) in the process of constituting knowledge - an importance which, at the level of ordinary, non-scientific knowledge, is also stressed by modern developmental psychology. ${ }^{44}$ In the passage quoted above on the young child, we saw that Schopenhauer was on the verge of this insight. He might have reached it, if...

But enough of if-history, which in the end is always unjust. It is almost symbolic that Schopenhauer died at virtually the same time when Darwin published his Origin of Species. Schopenhauer lived before the rise of modern biology and modern psychology and thus he could express his new insights

\footnotetext{
${ }^{43}$ Cf. Popper, op. cit., p. 24.

${ }^{44}$ Cf. for example Jean Piaget, Epistémologie génétique (Paris, 1970), passim.
} 
only in the old language of metaphysics. We began this paper by observing that Schopenhauer stands between Enlightenment and Romanticism; we may add now that he also stands between Romanticism and later 19th-century realism. This may even contribute to his notorious "inconsistency"; but surely it contributes no less to his fascination for the student of the history of ideas.

Acknowledgements - I am grateful to Floris Cohen for both many stimulating conversations on the subject and careful revision of the manuscript, and to Ida Cranakis for giving the manuscript the linguistic finishing touch. 